\title{
The Concept of Planetary Boundaries for Sustainable Development: A Review
}

\author{
Solomon Kai Bona ${ }^{1 *} \quad$ Dereje Alemu Bekele ${ }^{2}$ Hazhar Sami Haji ${ }^{1} \quad$ Tariq A. Bhat ${ }^{1}$ \\ 1.Division of Environmental Sciences, Sher-e-Kashmir University of Agricultural Sciences and Technology of \\ Kashmir, Shalimar, 190025, Srinagar, Jammu and Kashmir, India \\ 2.Assosa Agricultural Research Centre, Ethiopian Institute of Agricultural Research, Addis Ababa, Ethiopia,
} P.O.Box 2003

\begin{abstract}
The concept of the planetary boundaries (PB) is a reasonable scientific approach towards achieving the sustainable development goals (SDGs). It started in 2009 with a group of scientists at the Stockholm Resilience Center (SRC) in Sweden with the aim of showing a safe operating space for human development and wellbeing through scientific research by quantifying what they refer to as "planetary boundaries". But in other for the concept of the PB to thoroughly address the matters of the SDGs which does not only include environmental sustainability but also social issues, human prosperity, and governance, the concept of the PB has in combination with social boundaries and governance approaches created a sphere of reasonable ideas towards achieving the SDGs. The sustainable development trajectories of the PB comprising of six major structural transformations ensures that the world continues to develop economically while staying within planetary boundaries. Therefore, it has to take the cooperative efforts of all nations in the world to tackle, and to mitigate the overwhelming effects we have caused on our "good planet". Humans should realize that our planet has tried in all its "resilient capabilities "to condone all our exploitations, but it seems we have squeezed it too much and it is deflating. We need to build resilience to the unexpected (resilience thinking); we need to be prepared for the unexpected, both to be able to cope with "shocks" and to take advantage of "potentially positive surprises." This review tries to put together the different research ideas towards achieving the aim of the concept of the PB.
\end{abstract}

Keywords: Planetary Boundaries, Social Boundaries, Earth System Governance, SDGs

DOI: $10.7176 / \mathrm{JLPG} / 112-21$

Publication date:August $31^{\text {st }} 2021$

\section{Introduction}

The Stockholm Resilience Center (SRC) in Sweden brought about the idea of the concept of the planetary boundaries in 2009 in other to show a safe operating space for human development and wellbeing. They made the first attempt at identifying planetary boundaries for key Earth System processes associated with dangerous thresholds, the crossing of which could push the planet out of the desired Holocene state (Rockström et al. 2009 a). Out of this attempt, they concluded that from all the research they conducted, Earth has nine (9) boundaries that we should not cross. And that transgressing any or all of those boundaries will lead planet Earth to a very dangerous end. This concept has used other concepts that describe global environmental constraints: "carrying capacity", "sustainable consumption and production", "guardrails", "tipping points", "footprints", "safe operating space" or "planetary boundaries" as a shoulder to stand on in other to go beyond what all these concepts describe to indicate a safe zone for humanity's innovation, growth and development in the pursuit of human prosperity in an increasingly populated and wealthy world (Rockström et al. 2013).

But, the concept of the planetary boundaries does not stand alone in other for it to be the basis for sustainable development. Since the sustainable development goals (SDGs) only specify 6 goals namely: SDG 6 (freshwater supply), SDG 11 (sustainable cities), SDG 12 (sustainable production and consumption), SDG 13 (climate safety), SDG 14 (conserving marine ecosystems), and SDG 15 (conserving terrestrial ecosystems) in relation to environmental sustainability defined as the climate system is stable, biodiversity is conserved, ecosystems function well, freshwater is secured, rural and urban settlements are protected from pollution and are resilient to climate shocks (TWI2050. 2018); and the rest of the other goals are in relation to social inclusion, human prosperity, and good governance.

Therefore, the planetary boundaries in combination with the complementary concept of social boundaries has been inducted since the UN Conference on Sustainable Development in June 2012 (known as Rio+20), and the High-Level Summit on the Millennium Development Goals in 2013 in other to achieve sustainable development by ensuring that all people have the resources needed - such as food, water, health care, and energy - to fulfil their human rights. Thus, the use of the Earth-system resources by humanity will not lead to the crossing of the planetary boundaries' control variables thereby sustaining the Earth-system on a stable and resilient platform for human development and wellbeing (Raworth 2012). 


\section{The Earth boundaries as a necessary tool}

For humanity to stay within a safe operating space, the planetary boundaries have set up quantitative limits that should not be crossed. This somehow makes it very different and necessary from other concepts dealing with environmental constraints. From the quantification of the control variables, they have estimated as of 2009 that humanity has already transgressed three planetary boundaries: for climate change, rate of biodiversity loss (2009) renamed as biosphere integrity (2015), and changes to the global nitrogen cycle; in 2015, phosphorus was reported to have also been crossed (Steffen et al. 2015) as shown in Table 1. And the interdependencies of the planetary boundaries makes it so intricate that by transgressing one, may both shift the position of other boundaries or cause them to be transgressed. The proposed concept of "planetary boundaries" lays the groundwork for shifting our approach to governance and management, away from the essentially sectoral analyses of limits to growth aimed at minimizing negative externalities, toward the estimation of the safe space for human development. Planetary boundaries define, as it were, the boundaries of the "planetary playing field" for humanity if we want to be sure of avoiding major human-induced environmental change on a global scale (Rockström et al. 2009 a).

Table 1. The updated control variables and their current values, along with the proposed boundaries and zones of uncertainty

\begin{tabular}{|c|c|c|c|c|}
\hline $\begin{array}{l}\text { Earth-system } \\
\text { process }\end{array}$ & Parameters/Control variable & $\begin{array}{c}\text { Proposed boundary } \\
\text { (Zone of } \\
\text { uncertainty) }\end{array}$ & $\begin{array}{c}\text { Current Status } \\
(2009 / 2015)\end{array}$ & $\begin{array}{l}\text { Pre- } \\
\text { industrial } \\
\text { value }\end{array}$ \\
\hline Climate change & $\begin{array}{l}\text { (i) Atmospheric carbon } \\
\text { dioxide concentration (ppm by } \\
\text { volume) } \\
\text { (ii) Change in radiative forcing } \\
\text { (watts per metre squared) }\end{array}$ & $\begin{array}{l}350 \\
1\end{array}$ & $\begin{array}{l}387 / 398.5 \\
1.5 / 2.3\end{array}$ & $\begin{array}{l}280 \\
0\end{array}$ \\
\hline $\begin{array}{l}\text { Rate of biodiversity } \\
\text { loss ( } 2009) \text { to } \\
\text { change in biosphere } \\
\text { integrity (2015) }\end{array}$ & $\begin{array}{l}\text { Genetic diversity: } \\
\text { Extinction rate } \\
\text { Functional diversity: } \\
\text { Biodiversity } \\
\text { Intactness Index (BII) } \\
\text { Note: These are interim } \\
\text { control variables until more } \\
\text { appropriate ones are } \\
\text { developed. }\end{array}$ & $\begin{array}{l}<10 \text { E/MSY }(10- \\
100 \text { E/MSY })\end{array}$ & $\begin{array}{l}>100 / 100-1000 \\
\text { E/MSY } \\
84 \% \text {, applied to } \\
\text { southern Africa } \\
\text { only }\end{array}$ & $0.1-1$ \\
\hline $\begin{array}{l}\text { Biogeochemical } \\
\text { flows: (P and N } \\
\text { cycles) (R2009: } \\
\text { Biogeochemical } \\
\text { flows:(interference } \\
\text { with P and N } \\
\text { cycles)) }\end{array}$ & $\begin{array}{l}\text { N Global: Industrial and } \\
\text { intentional biological fixation } \\
\text { of } \mathrm{N} \\
P \text { : Global: P flow from } \\
\text { freshwater } \\
\text { systems into the ocean } \\
\text { P Regional: P flow from } \\
\text { fertilizers to erodible soils }\end{array}$ & 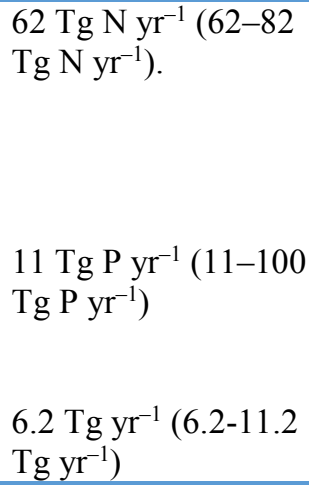 & $\begin{array}{l}\sim 150 \mathrm{Tg} \mathrm{N} \mathrm{yr}^{-1} \\
\sim 22 \mathrm{Tg} \mathrm{P} \mathrm{yr}^{-1} \\
\sim 14 \mathrm{Tg} \mathrm{P} \mathrm{yr}^{-1}\end{array}$ & 0 \\
\hline $\begin{array}{l}\text { Stratospheric ozone } \\
\text { depletion }\end{array}$ & $\begin{array}{l}\text { Concentration of ozone } \\
\text { (Dobson unit) }\end{array}$ & $\begin{array}{l}276(<5 \% \text { reduction } \\
\text { from pre-industrial } \\
\text { level) }\end{array}$ & $\begin{array}{l}283 / \text { Only } \\
\text { transgressed over } \\
\text { Antarctica in } \\
\text { Austral spring } \\
(\sim 200 \text { DU) }\end{array}$ & 290 \\
\hline Ocean acidification & $\begin{array}{l}\text { Global mean saturation state } \\
\text { of aragonite in surface sea } \\
\text { water }\end{array}$ & $\begin{array}{l}2.75 / \geq 80 \% \text { of the } \\
\text { preindustrial } \\
\text { aragonite saturation } \\
\text { state. }\end{array}$ & $\begin{array}{l}2.90 / \sim 84 \% \text { of the } \\
\text { pre-industrial } \\
\text { Aragonite } \\
\text { saturation state. }\end{array}$ & 3.44 \\
\hline
\end{tabular}




\begin{tabular}{|c|c|c|c|c|}
\hline $\begin{array}{l}\text { Global freshwater } \\
\text { use }\end{array}$ & $\begin{array}{l}\text { Global: Maximum amount of } \\
\text { consumptive blue water use } \\
\left(\mathrm{km}^{3} \mathrm{yr}^{-1}\right) \\
\text { Basin: Blue water withdrawal } \\
\text { as \% of mean monthly river } \\
\text { flow }\end{array}$ & $\begin{array}{l}\text { Global: } 4000 \mathrm{~km}^{3} \\
\mathrm{yr}^{-1}\left(4000-6000 \mathrm{~km}^{3}\right. \\
\left.\mathrm{yr}^{-1}\right) \\
\text { Basin: Maximum } \\
\text { monthly withdrawal } \\
\text { as a percentage } \\
\text { of mean monthly } \\
\text { river flow. For low- } \\
\text { flow months: } 25 \% \\
(25-55 \%) \text {; for } \\
\text { intermediate flow } \\
\text { months: } 30 \% \text { (30- } \\
60 \%) \text {; for high-flow } \\
\text { months: } 55 \% \text { (55- } \\
85 \%)\end{array}$ & $\sim 2600 \mathrm{~km}^{3} \mathrm{yr}^{-1}$ & 425 \\
\hline Change in land use & $\begin{array}{l}\text { Global: Area of forested land } \\
\text { as \% } \\
\text { of original forest cover. } \\
\text { Biome: Area of forested land } \\
\text { as \% } \\
\text { of potential forest }\end{array}$ & $\begin{array}{l}\text { Global: } 75 \%(75- \\
54 \%) \text { Values are a } \\
\text { weighted average of } \\
\text { the three individual } \\
\text { biome boundaries } \\
\text { and their uncertainty } \\
\text { zones } \\
\text { Biome: Tropical: } \\
85 \%(85-60 \%) \\
\text { Temperate: } 50 \% \\
(50-30 \%) \\
\text { Boreal: } 85 \%(85- \\
60 \%)\end{array}$ & $11.7 / 62 \%$ & Low \\
\hline $\begin{array}{l}\text { Atmospheric } \\
\text { aerosol } \\
\text { loading }\end{array}$ & $\begin{array}{l}\text { Global: Aerosol Optical Depth } \\
\text { (AOD), but much regional } \\
\text { variation } \\
\text { Regional: AOD as a seasonal } \\
\text { average over a region. South } \\
\text { Asian Monsoon used as a case } \\
\text { study }\end{array}$ & $\begin{array}{l}\text { Regional: (South } \\
\text { Asian Monsoon as a } \\
\text { case study): } \\
\text { anthropogenic total } \\
\text { (absorbing and } \\
\text { scattering) AOD } \\
\text { over Indian } \\
\text { subcontinent of } 0.25 \\
\text { (0.25-0.50); } \\
\text { absorbing (warming) } \\
\text { AOD less than } 10 \% \\
\text { of total AOD. }\end{array}$ & $\begin{array}{l}0.30 \text { AOD, over } \\
\text { South Asian } \\
\text { region. }\end{array}$ & \\
\hline $\begin{array}{l}\text { Introduction } \\
\text { of novel entities } \\
\text { (R2009: Chemical } \\
\text { pollution) }\end{array}$ & $\begin{array}{l}\text { No control variable currently } \\
\text { defined }\end{array}$ & $\begin{array}{l}\text { No boundary } \\
\text { currently identified, } \\
\text { but see boundary for } \\
\text { stratospheric ozone } \\
\text { for an example of a } \\
\text { boundary related to a } \\
\text { novel entity (CFCs). }\end{array}$ & \multicolumn{2}{|l|}{ To be determined } \\
\hline
\end{tabular}

Source: Rockström et al. 2009 b; Steffen et al. 2015

The categorization of the planetary boundaries has paved a pathway way for policy makers to be able to address environmental constraints in the local, regional, and global scale by giving heed to scientific advices and suggestions in the face of uncertainties. The thresholds have been set for each control variable of the Earth systems, and if crossed, then important subsystems, such as a monsoon system, could shift into a new state, often with deleterious or potentially even disastrous consequences for humans. The definition of most of these 
thresholds can be a critical value for one or more control variables, such as carbon dioxide concentration. A definite threshold is not certain for some of the subsystems of the Earth, although human actions that undermine the resilience of such processes or subsystems - for example, land and water degradation - can increase the risk that thresholds will also be crossed in other processes, such as the climate system (Rockström et al. 2009 b). The planetary boundaries have been conceptually described to help us understand the difference between global thresholds, and the regional and local scale with no global threshold (Steffen et al. 2015) as shown in the figure 1 below. According to (Rockström et al. 2009 a), Process X is designed to avoid the crossing of a critical continental to global threshold in an Earth System process. Insufficient knowledge and the dynamic nature of the threshold generate a zone of uncertainty about its precise position, which informs the determination of where to place the boundary; and in Process Y, there is no global threshold effect as far as we know, but exceeding the boundary level will lead to significant interactions with regional and global thresholds and/or may cause a large number of undesired threshold effects at the local to regional scale, which in aggregate add up to a serious global concern for humanity.

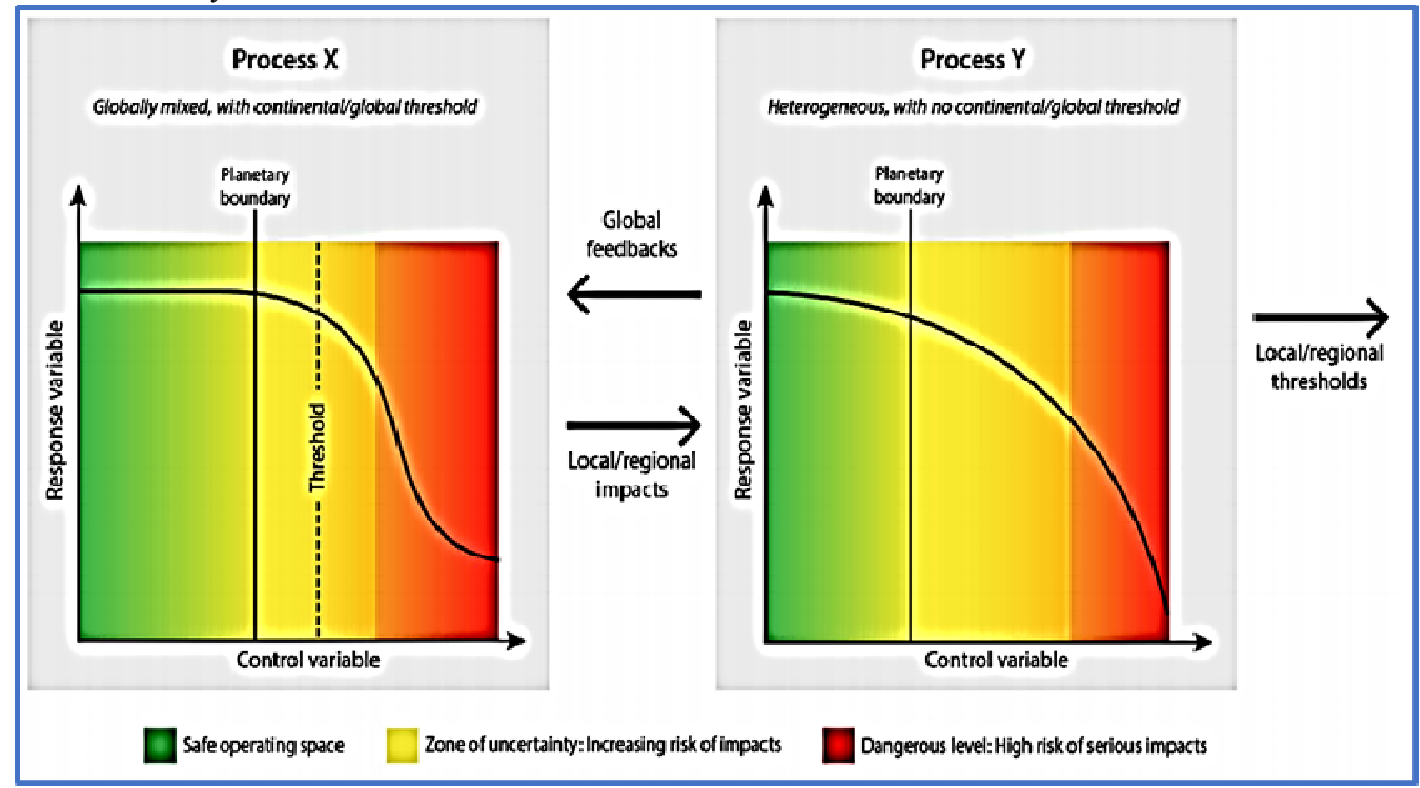

Figure 1: Conceptual Description of Planetary boundaries (Source: Steffen et al. 2015)

\section{The planetary and social boundaries for sustainable development}

For humanity operate in a safe zone that is within the planetary boundaries it has to take the complex intertwined concept of the both the planetary and social boundaries. These two boundaries have relational impact on each other, as Kate Raworth puts it "The aggravation of poverty can be driven by environmental stress, and vice versa. A poorly designed policy with a goal of retreating within the $\mathrm{PB}$, can regress people beneath the social boundaries which can lead to a further degradation of the Earth-systems. Policies that are well framed to address 'socioecological' issues can stand the test of time to eradicate poverty and boost Earth-systems sustainability, thereby leading humanity into what she called "the doughnut" from both sides" (Raworth 2012) as shown in Figure 2. "There are important characteristics that these two concepts have in common to achieving sustainable development" stated Kate Raworth as given below:

1. The fundamentals of sustainable development: All human lives should be constructed upon a social foundation and below environment ceilings. Neither should be crossed.

2. Boundaries based on norms: The normativeness of both boundaries is clear. The social boundaries determine what makes up human deprivation; so, it is with the planetary boundaries which is based perceptions of risk, and of the desirability of staying within the Holocene thereby setting boundaries in relation to natural resources.

3. Global to local: The social and planetary boundaries can have downscaled effects from global to regional to local. An example is a tipping point towards localised flash flooding and soil degradation can be as a result of deforestation within a country, long before it affects land-use change at the Earth-system scale. Likewise, minority social groups within a country may experience severe marginalisation long before their exclusion is evident in national, let alone global, data on social inequalities.

Biodiversity, ecosystem services, and human wellbeing are so intertwined that affecting anyone will lead to a corresponding effect on the other. The ecosystem with its foundational biodiversity counterpart plays a very important role to sustaining and improving human wellbeing by it various services such as provision of basic 
amenities; regulation of earth system services such as climate, floods etc.; its cultural services such as recreation, aesthetic enjoyment, and spiritual fulfillment; and its supportive role in soil formation, photosynthesis, and nutrient cycling. It is considered that for humanity to be well sustained the composition of five fundamental requirement should be met vis: a good life, a healthy living, good social relations, security, and the freedom of choice and action. Many factors from which human sustainability arises are connected to biodiversity and ecosystem services. Therefore, humanity should be seen as part of a web of intricate connections that are dependent on each other (Anonymous 2005).

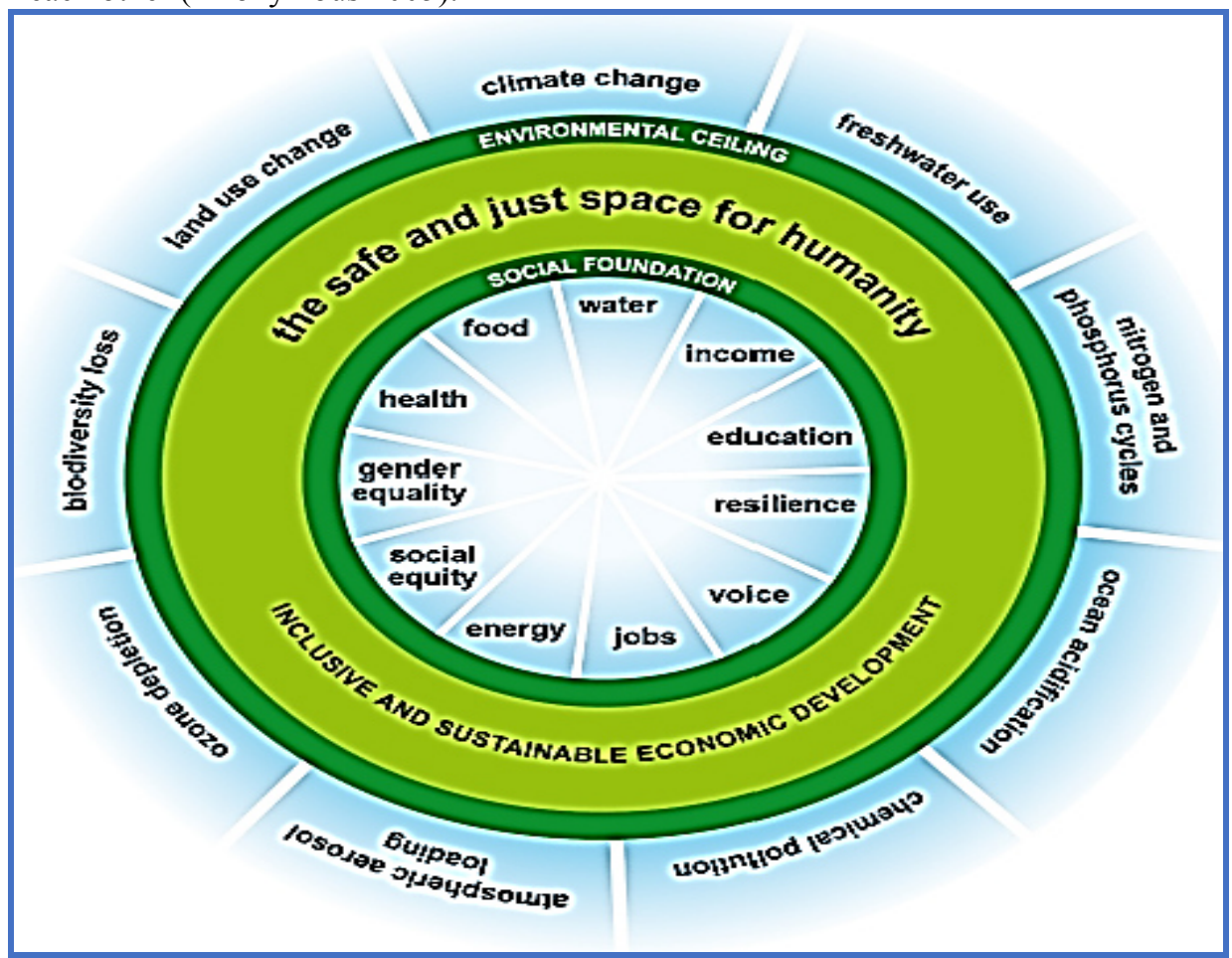

Figure 2: A safe and just space for humanity to thrive in. (Source: Kate Raworth 2012).

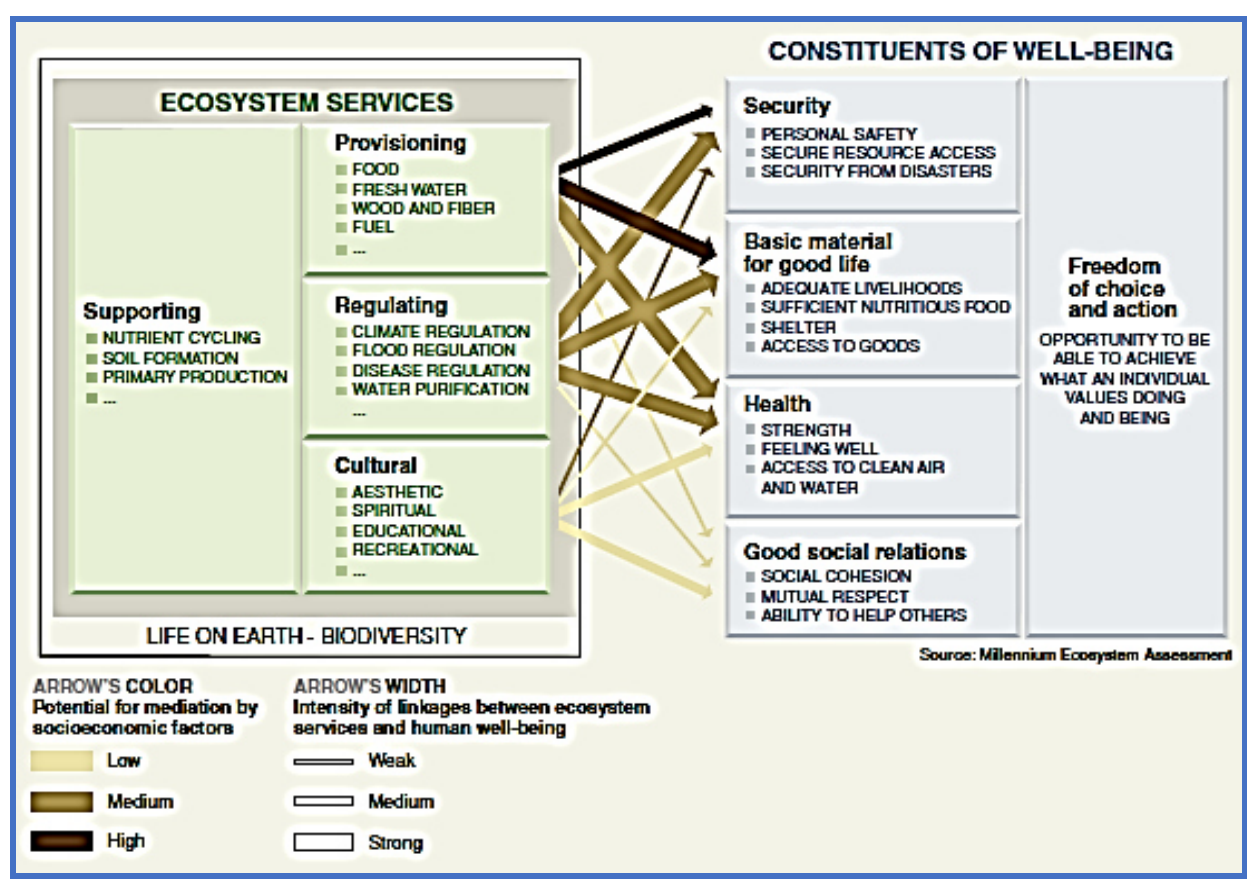

Figure 3: Linkages among Biodiversity, Ecosystem Services, and Human Well-being (Source: Anonymous 2005) 


\section{Environmental/Earth system governance (ESG)}

The studies of the nine planetary boundaries have revealed that human activities are responsible for the multiple, interacting effects that cascade through the Earth systems. There are four identified interrelated global environmental governance challenges that the concept of the planetary boundaries (PBs) has brought upon governments and international institutions as put forward by (Galaz et al. 2012). The possible interventions are shown in Table 2:

1. The interplay between Earth system science and global policies and the implications of differences in risk perceptions in defining these boundaries.

2. The capacity of international institutions to deal with individual 'planetary boundaries', as well as interactions between them.

3. The role of international organizations in dealing with 'planetary boundaries' interactions.

4. The role of global governance in framing social-ecological innovations.

Table 2: Planetary boundaries and possible intervention points.

\begin{tabular}{|c|c|c|}
\hline Possible intervention & Potential & Limitations \\
\hline $\begin{array}{l}\text { Intergovernmental } \\
\text { platform/s for iterated } \\
\text { global and regional } \\
\text { environmental } \\
\text { assessments }\end{array}$ & $\begin{array}{l}\text { Could help overcome institutional } \\
\text { fragmentation and monitoring gaps. } \\
\text { Could provide important space for } \\
\text { deliberation between science and } \\
\text { societal interests }\end{array}$ & $\begin{array}{l}\text { Impact on international and national } \\
\text { policies cannot be taken for granted, } \\
\text { especially in cases where causality is } \\
\text { complex and interventions are perceived } \\
\text { to conflict with national interests. }\end{array}$ \\
\hline Overarching principles & $\begin{array}{l}\text { Have the ability to govern the } \\
\text { interaction between different } \\
\text { international institutions, regulate } \\
\text { norm-conflicts, and increase efficiency } \\
\text { and effectiveness by providing for } \\
\text { general standards of behaviour. }\end{array}$ & $\begin{array}{l}\text { Unclear applicability for 'planetary } \\
\text { boundaries'; likely to be contested with } \\
\text { unclear practical implications. }\end{array}$ \\
\hline Interaction management & $\begin{array}{l}\text { International inter-organizational } \\
\text { learning, knowledge diffusion and } \\
\text { joint management could lead to } \\
\text { international policy integration able to } \\
\text { deal with interactions between } \\
\text { 'planetary boundary' processes. }\end{array}$ & $\begin{array}{l}\text { Unclear how to integrate issues related to } \\
\text { 'non-regimes', as well as rapidly } \\
\text { unfolding surprises where international } \\
\text { institutions are missing, or where } \\
\text { institutional settings are complex and } \\
\text { contested. }\end{array}$ \\
\hline $\begin{array}{l}\text { Expanding the mandates } \\
\text { of international } \\
\text { organizations }\end{array}$ & $\begin{array}{l}\text { Negative institutional interactions can } \\
\text { be identified, and countermeasures } \\
\text { negotiated and implemented. Regular } \\
\text { assessments can support international } \\
\text { attempts to stay within planetary } \\
\text { boundaries. }\end{array}$ & $\begin{array}{l}\text { Difficult to assign one single } \\
\text { international organization to oversee } \\
\text { suite of activities, and possibilities of } \\
\text { negative institutional side effects due to } \\
\text { institutional fragmentation at the global } \\
\text { level. }\end{array}$ \\
\hline multi-actor & $\begin{array}{l}\text { Can function as self-organized } \\
\text { complements to formal international } \\
\text { mechanisms, and provide bridging } \\
\text { function at the international level } \\
\text { especially for interactions between } \\
\text { 'planetary boundary' processes. }\end{array}$ & $\begin{array}{l}\text { Collective action problems remain, and } \\
\text { could lead to the diffusion of } \\
\text { responsibility. Possible externalities } \\
\text { difficult to deal with at the international } \\
\text { level. }\end{array}$ \\
\hline $\begin{array}{l}\text { Global policies to support } \\
\text { innovation }\end{array}$ & $\begin{array}{l}\text { Could help support, frame and upscale } \\
\text { innovations that address 'planetary } \\
\text { boundaries', by supporting the } \\
\text { generation and stewardship of } \\
\text { ecosystem services. }\end{array}$ & $\begin{array}{l}\text { Possible externalities and conflicts } \\
\text { emerging as the result of unintended } \\
\text { effects of innovation need to be dealt } \\
\text { with at the international level. }\end{array}$ \\
\hline
\end{tabular}

Source: Galaz et al. 2012

\section{The Sustainable Development Trajectory}

Form the studies on the concept of the planetary boundaries arises the sustainable development (SD) trajectory to put forward six major structural transformations that are important and necessary to be addressed by governments and international institutions for a fair play within the planetary boundaries and a continual economic development for all the world. "Each of the transformations outlined below requires detailed strategies, major ongoing research and development (R\&D) efforts and continuous problem solving. A lot remains unknown about how exactly these transformations might work. Yet, we do know enough to get started with confidence that remaining issues can be resolved" (Rockström et al. 2013). 
i. The Energy Transformation: Perhaps the most important transformation for the sustainable development trajectory is the shift towards a low-carbon economy.

ii. The Food Security Transformation: Rising food production must be decoupled from unsustainable utilization of water, energy, fertilizers, chemicals and land. This will require a multi-faceted agroecological intensification of food production.

iii. The Urban Sustainability Transformation: Resource-efficient investments like urban infrastructure investments; and to increase resilience, cities must inter alia upgrade their infrastructure, introduce zoning and siting policies to avoid floods, and manage water resources and waste sustainably.

iv. The Population Transformation: Population growth needs to be slowed as much as possible by a voluntary fertility reduction.

v. The Biodiversity Management Transformation: Managing the world's species that will operate at local and regional scales where the species live. It would also include strategies for preserving the six critical biomes that constitute key "global regulating systems" of concern for humanity as a whole, irrespective of where one lives. These biomes include the Polar regions, the remaining tropical rainforests, the ocean marine system, the world's permafrost regions, temperate forests, and the world's savannahs.

vi. The Private and Public Governance Transformation: Inter alia by recognizing that public policy decisions must be made on the basis of scientific evidence, or that multi-national companies must be made accountable for their actions.

\section{Sustainability for humanity and the planet}

Figure 4 and Box 1 explains how the combination of Millennium Development Goals (MDGs) with the planetary boundaries' target referred to as "planetary must-haves" will lead to a unification of the SDGs to six fundamentally proposed SDGs with 2030 provisional aims. The new paradigm of the world must now be an economy that serves the needs of the society and a society that operates within the stable confines of the Earth's life-support system/resilient Earth-system. For this to work out, "First, however, we need to reframe the UN paradigm of three pillars of sustainable development - economic, social and environmental - and instead view it as a nested concept. The global economy services society, which lies within Earth's life-support system" (Griggs et al. 2013).

There needs to be a redefinition of sustainable development from the laid out one given by the 1987 UN World Commission on Environment and Development (the Brundtland Commission), to "development that meets the needs of the present while safeguarding Earth's life-support system, on which the welfare of current and future generations depends" (Griggs et al. 2013). The 'planetary must-haves' for human development and wellbeing shown in Figure 4 was produced by connecting the planetary boundaries concept with credible scientific research and the already existing international processes such as the United Nations Framework Convention on Climate Change.

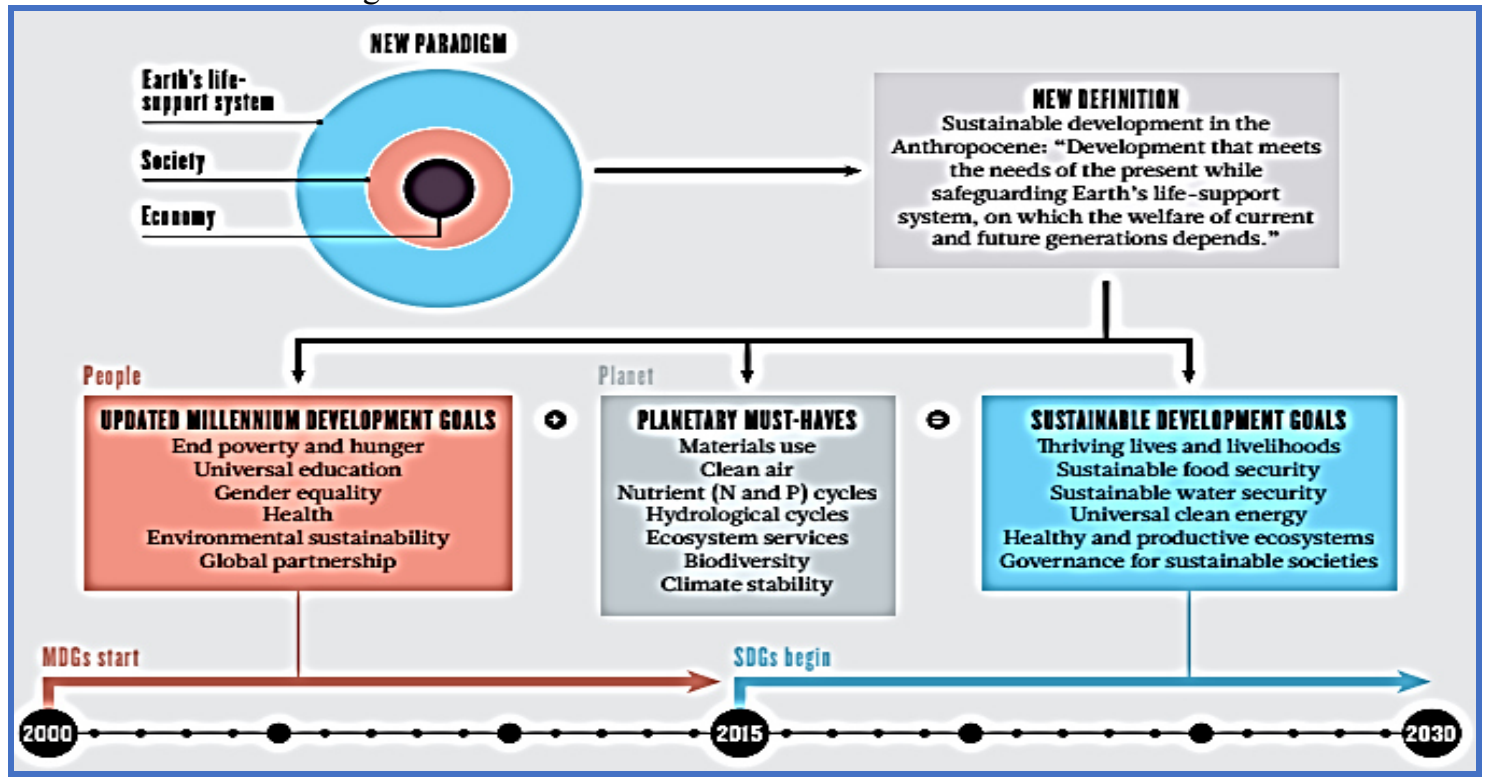

Figure 4. A unified framework with conditions necessary to assure the stability of Earth's systems. (Source: Griggs et al. 2013) 


\begin{tabular}{|c|c|c|}
\hline \multicolumn{3}{|c|}{ SIX SUSTAINABLE DEVELOPMENT GOALS } \\
\hline \multicolumn{3}{|c|}{ Some provisional targets for 2030} \\
\hline $\begin{array}{l}\text { - Goal 1: Thriving lives and livelihoods. End } \\
\text { poverty and improve well-being through } \\
\text { access to education, employment and } \\
\text { information, better health and housing, and } \\
\text { reduced inequality while moving towards } \\
\text { sustainable consumption and production. } \\
\text { This extends many targets of the } \\
\text { Millennium Development Goals (MDGs) on } \\
\text { poverty, health and urban environments } \\
\text { and applies them to developed nations. It } \\
\text { should include targets on clean air that build } \\
\text { on World Health Organization guidelines for } \\
\text { pollutants such as black carbon'; reductions } \\
\text { in emissions of stratospheric ozone-depleting } \\
\text { substances in line with projections from the } \\
\text { Montreal Protocol; critical loads for man-made } \\
\text { chemical compounds and toxic materials; and } \\
\text { sustainable practices for extraction, use and } \\
\text { recycling of scarce minerals and metals and } \\
\text { other natural resources. } \\
\text { - Goal } 2 \text { : Sustainable food security. } \\
\text { End hunger and achieve long-term food } \\
\text { security - including better nutrition - } \\
\text { through sustainable systems of production, } \\
\text { distribution and consumption. } \\
\text { The MDG hunger target should be extended } \\
\text { and targets added to limit nitrogen and } \\
\text { phosphorus use in agriculture } \\
\text { use efficiency should improve by } 20 \% \text { by } \\
2020 ; \text { no more than } 35 \text { million tonnes of } \\
\text { nitrogen per year should be extracted from the }\end{array}$ & $\begin{array}{l}\text { - Goal 4: Universal clean energy. Improve } \\
\text { universal, affordable access to clean energy } \\
\text { that minimizes local pollution and health } \\
\text { impacts and mitigates global warming. } \\
\text { This contributes to the UN commitment } \\
\text { to sustainable energy for all, and addresses } \\
\text { MDG targets on education, gender equity and } \\
\text { health. To ensure at least a } 50 \% \text { probability of } \\
\text { staying within } 2^{\circ} \mathrm{C} \text { warming } \\
\text { targets should aim for global greenhouse- } \\
\text { gas emissions to peak in } 2015-20 \text {, drop by } \\
3-5 \% \text { a year until } 2030 \text {, and fall by } 50-80 \% \\
\text { by } 2050 \text {. } \\
\text { - Goal 5: Healthy and productive } \\
\text { ecosystems. Sustain biodiversity and }\end{array}$ & $\begin{array}{l}\text { ecosystem services through better } \\
\text { management, valuation, measurement, } \\
\text { conservation and restoration. } \\
\text { This combines the MDG environmental } \\
\text { targets with } 2030 \text { projections of the Aichi } \\
\text { Targets adopted by the Convention on } \\
\text { Biological Diversity (see www.cbd.int/sp/ } \\
\text { targets). Extinctions should not exceed ten } \\
\text { times the natural background rate. At least } \\
70 \% \text { of species in any ecosystem and } 70 \% \\
\text { of forests should be retained. Aquatic and } \\
\text { marine ecosystems should be managed } \\
\text { to safeguard areas crucial for biodiversity, } \\
\text { ecosystem services and fisheries. } \\
\text { - Goal } 6: \text { Governance for sustainable } \\
\text { societies. Transform governance and } \\
\text { institutions at all levels to address the other } \\
\text { five sustainable development goals. } \\
\text { This would build on MDG partnerships } \\
\text { and incorporate environmental and social } \\
\text { targets into global trade, investment and } \\
\text { finance. Subsidies on fossil fuels and policies } \\
\text { that support unsustainable agricultural and } \\
\text { fisheries practices should be eliminated by } \\
2020 ; \text { product prices should incorporate } \\
\text { social and environmental impacts. National } \\
\text { monitoring, reporting and verification } \\
\text { systems must be established for sustainable- } \\
\text { development targets; and open access to } \\
\text { information and decision-making processes } \\
\text { should be secured at all levels. }\end{array}$ \\
\hline
\end{tabular}

Box 1: Some provisional targets for 2030 (Source: Griggs et al. 2013)

\section{Conclusion}

Our world is not on a smooth path to achieving the Sustainable Development Goals (SDGs). It has to take the cooperative efforts of all nations in the world to tackle, and to mitigate the overwhelming effects we have caused on our "good planet". The "tipping points" of all the Planetary Boundaries are feasible i.e., "we could reach them." The socioecological states of our world have gone through lots of changes or shifts and these are not good neither for us nor for future generations that will come. Humans should realize that our planet has tried in all its "resilient capabilities" to condone all our exploitations, but it seems we have squeezed it too much and it is deflating. We need to build resilience to the unexpected (resilience thinking); we need to be prepared for the unexpected, both to be able to cope with "shocks" and to take advantage of "potentially positive surprises." The precautionary principle which is a "go-slow-and-ask-smart-questions" kind of a principle must be part and parcel of our daily lives, to be applied where there are indications of potentially serious consequences if we do not get things right.

\section{References}

Anonymous. (2005), "Millennium Ecosystem Assessment. Ecosystems and Human Well-Being: Biodiversity Synthesis. (2005) World Resources Institute, Washington, DC", Ecological Management \& Restoration 6 (3), 226-227

Galaz, Victor, Frank Biermann, Beatrice Crona, Derk Loorbach, Carl Folke, Per Olsson, Måns Nilsson, Jeremy Allouche, Åsa Persson, and Gunilla Reischl. (2012),. "'Planetary Boundaries'-Exploring the Challenges for Global Environmental Governance", Current Opinion in Environmental Sustainability 4, 80-87. https://doi.org/10.1016/j.cosust.2012.01.006.

Griggs, David, Mark Stafford-Smith, Owen Gaffney, Johan Rockström, Marcus C. Öhman, Priya Shyamsundar, Will Steffen, Gisbert Glaser, Norichika Kanie, and Ian Noble. (2013), "Policy: Sustainable Development Goals for People and Planet", Nature 495, 305-307. https://doi.org/10.1038/495305a.

Raworth, Kate. (2012), “A Safe and Just Space for Humanity: Can We Live within the Doughnut”, Oxfam Policy and Practice: Climate Change and Resilience 8(1), 1-26.

Rockström, Johan, Jeffrey Sachs, Guido Schmidt-traub, and Marcus Öhman. (2013), "Sustainable Development and Planetary Boundaries", Sustainable Developmen Solutions Network, 1-46.

Rockström, Johan, Will Steffen, Kevin Noone, Åsa Persson, F. Stuart Chapin, Eric F. Lambin, Timothy M. Lenton, Marten Scheffer, Carl Folke, Hans Joachim Schellnhuber, Björn Nykvist, Cynthia A. De Wit, et al. (2009), “A Safe Operating Space for Humanity”, Nature 461, 472-475 . https://doi.org/10.1038/461472a.

Rockström, Johan, Will Steffen, Kevin Noone, Åsa Persson, F. Stuart Chapin, Eric Lambin, Timothy M. Lenton, 
Marten Scheffer, Carl Folke, Hans Joachim Schellnhuber, Björn Nykvist, Cynthia A. de Wit, et al. (2009), "Planetary Boundaries: Exploring the Safe Operating Space for Humanity", Ecology and Society 14 (2), 32. https://doi.org/10.5751/ES-03180-140232.

Steffen, Will, Katherine Richardson, Johan Rockström, Sarah E. Cornell, Ingo Fetzer, Elena M. Bennett, Reinette Biggs, et al. (2015), "Planetary Boundaries: Guiding Human Development on a Changing Planet", Science 347 (6223). https://doi.org/10.1126/science.1259855.

TWI2050 - The World in 2050. (2018), "Transformations to Achieve the Sustainable Development Goals Report Prepared by The World in 2050 Initiative”, International Institute for Applied Systems Analysis, 7-8. https://doi.org/10.22022/TNT/07-2018.15347. 